\title{
Prevalence, incidence and distribution of citrus variegated chlorosis in Bahia, Brazil
}

\author{
Francisco F. Laranjeira ${ }^{1}$, Leonardo G. Silva ${ }^{2}$, Eliana L. Fonseca ${ }^{3}$, Suely X.B. Silva ${ }^{2}$, Jemine B. Rocha ${ }^{2}$, \\ Hermes P. Santos-Filho ${ }^{1}$, Carlos Alberto S. Ledo ${ }^{1} \&$ Bernhard Hau ${ }^{4}$
}

${ }^{1}$ Embrapa Mandioca \& Fruticultura Tropical, 44380-000, Cruz das Almas, BA, Brazil; ${ }^{2}$ Agência Estadual de Defesa Agropecuária da Bahia - ADAB, 44380-000, Cruz das Almas, BA, ${ }^{3}$ Departamento de Geografia, Universidade Federal do Rio Grande do Sul, 91501-970, Porto Alegre, RS, Brazil; ${ }^{4}$ Institute of Plant Diseases and Plant Protection, Hannover University, Germany

Author for correspondence: Francisco F. Laranjeira, e-mail: chico@cnpmf.embrapa.br

\begin{abstract}
Citrus variegated chlorosis (CVC) is one of the most important diseases for Brazilian citriculture. It is caused by Xylella fastidiosa subsp. pauca, a xylem limited, cycadelid and budwood transmitted bacterium. In Bahia, the second most important citrus region in Brazil, CVC has been present since 1997. Our objectives were to characterize the regional spatial pattern of CVC and to establish a relationship between epidemiological variables and horticultural practices, as well as to evaluate whether control measures used so far have been effective and, based on that, to conceive suitable control measures. A series of surveys were performed in two regions of Bahia State (Recôncavo Baiano and Litoral Norte), along with a survey of horticultural and control practices associated with sampled groves. CVC was restricted to Litoral Norte region, especially to three municipalities along the border between Bahia and Sergipe States. The mean CVC incidence in these municipalities followed a gradient, higher in the countryside and decreasing along the coast. Presence and dissemination of CVC was related to poor nursery practices, a massive use of a susceptible orange variety, and an extreme concentration of orange groves in high incidence municipalities, as well as to the absence of specific CVC control. Considering that CVC was not found in Recôncavo Baiano, this region could be considered a "CVC free zone" by the local government.
\end{abstract}

Keywords: Xylella fastidiosa, Citrus sinensis, Orange, CVC.

\section{RESUMO}

Prevalência, incidência e distribuição da clorose variegada dos citros na Bahia

A clorose variegada dos citros (CVC) - causada por Xylella fastidiosa subsp. pauca, bactéria limitada ao xilema, transmitida por insetos cicadelídeos e por material de propagação - é uma das doenças mais importantes da citricultura brasileira. Na Bahia, segundo maior produtor do Brasil, a CVC está presente desde 1997. Os objetivos deste trabalho foram caracterizar o padrão espacial regional da CVC, estabelecer relações entre as variáveis epidemiológicas e práticas horticulturais e avaliar se as medidas de controle usadas até o momento tem sido efetivas. Uma série de prospecções foi realizada em duas regiões da Bahia (Recôncavo Baiano e Litoral Norte), assim como uma prospecção das práticas horticulturais e de controle da doença associadas aos pomares amostrados. A CVC está restrita à região do Litoral Norte, com maior incidência nos três municípios que fazem fronteira com o Estado de Sergipe. A incidência média nesses municípios seguiu um gradiente, maior no interior e decrescendo em direção ao litoral. A presença e disseminação da CVC foi relacionada ao manejo inadequado de viveiros, uso massivo de variedade copa suscetível, extrema concentração de pomares de laranja doce em municípios de alta incidência e ausência de medidas específicas de controle da doença. O Recôncavo Baiano poderia ser considerado como região livre da CVC pois nenhuma planta sintomática foi encontrada em qualquer das prospecções.

Palavras-chave: Xylella fastidiosa, Citrus sinensis, laranja, CVC.

\section{INTRODUCTION}

Brazil is the world's largest citrus producer and exporter of frozen concentrated orange juice. Although most groves are established in the State of São Paulo, citrus plants are grown in all Brazilian regions and represent an important income source for small farmers in many of them. Bahia, a State in the Northeast Region of Brazil, has the second largest citrus belt in this country, with more than 50,000 ha of orange groves (IBGE, 2004).
Despite the importance and vitality of Brazilian citriculture, few varieties are used to set the scion-rootstock combination and a special emphasis is put on plants of Pêra sweet orange (Citrus sinensis Osbeck) grafted on Rangpur lime (C. limonia Osbeck). In this situation, the dissemination of diseases is usually increased. Among the citrus diseases in Brazil, one of the most important is the citrus variegated chlorosis (CVC). Yield of severely affected plants may be reduced by more than 70\% (Ayres et al., 2001; Palazzo, 1993) and the most recent survey in São Paulo showed that 
$37 \%$ of orange trees had severe symptoms (Fundecitrus, 2006). Moreover, CVC also causes an increase in production costs (Tersi \& Rigolin, 2000).

CVC is caused by Xylella fastidiosa subsp. pauca (Schaad et al., 2004), a xylem-limited bacterium transmitted by cycadelid insects (Laranjeira et al., 2005a). Besides the transmission by vectors - 11 species of ten different genera have been confirmed - this bacterium may also be dispersed by infected propagation material such as nursery plants or budwood (Laranjeira et al., 2005a,b; Parra et al., 2005). Although CVC does not kill infected plants, it can cause yield reduction of more than $90 \%$ in highly susceptible varieties like Pêra sweet orange (Laranjeira \& Pompeu Júnior, 2002). Foliar symptoms are characterized by chlorosis on the adaxial surface and brown-reddish lesions on the abaxial surface, always corresponding to the chlorotic spots. Affected fruits have thin peel, early degreening, inhibited ripening and their size is diminished up to $65 \%$ (Laranjeira \& Palazzo, 1999). CVC was reported for the first time in 1987 in the State of São Paulo, Brazil and since then it has spread to other Brazilian regions and even to other countries of South and Central America (Laranjeira et al., 2005a; Aguilar et al., 2005). This disease has been controlled by a combination of different methods (Laranjeira et al., 2005b). In general the use of healthy propagation material is advised; in the State of São Paulo the production of nursery plants with protective screens has even been mandatory since 2003 (Carvalho, 2003). Groves up to six years old are protected by insecticide spraying on leaves or on the trunks. If plants show symptoms, despite the chemical control, those less than three years old or extremely affected are removed. Affected trees older than three years old are subjected to pruning of symptomatic branches (Fundecitrus, 2004). Although CVC incidence as a whole is increasing in São Paulo, its reduction in plants younger than three years has been attributed to the adoption of these control measures (Fundecitrus, 2006).

In Bahia, CVC was reported in 1997 in groves from Litoral Norte region, south of the border with the state of Sergipe (Santos Filho et al., 1997). Despite this finding, more extensive surveys were never done. Bahia's citriculture is basically exploited in two regions - Litoral Norte (LN) and Recôncavo Baiano (RB) - which are responsible for $69 \%$ and $20 \%$ of the production, respectively (IBGE, 2004). These regions differ with respect to their technological level, which is higher in LN, and although they are close to each other, their citrus belts are separated by a $100 \mathrm{~km}$ strip with no orange groves.

The lack of knowledge about CVC prevalence and distribution in Bahia has implied a paralysis in relation to control strategies. As CVC spread is unknown, it has not been possible to specifically devise adequate control measures for Bahian citriculture. Hence, efforts are limited to exclusion measures, preventing the transport of citrus material from other states to Bahia, but these measures are not applied to protect disease-free zones inside the state. In addition, no eradication program has been attempted.
The objectives of this work were to determine the prevalence and distribution of $\mathrm{CVC}$ in two citrus producing regions of Bahia, to test the hypothesis that CVC spread is related to concentration of orange groves and to horticultural practices, and to conceive suitable control measures.

\section{MATERIALS AND METHODS}

Considering the distinctive features of $\mathrm{LN}$ and $\mathrm{RB}$, separate surveys were carried out in the two regions and the stratification level was related to the municipalities. The choice of municipalities, number of samples and ratio between number of samples and number of orange hectares (Tables 1, 2 and 3) was made based on data from the Brazilian Institute of Geography and Statistics (IBGE, 2004). For the first survey, the decision on the total number of samples in each region was arbitrary, but the distribution by municipalities was based on the acreage under orange cultivation. Also, every municipality with more than 100 ha of orange groves had to be sampled.

Considering that a Bahian citriculture database was not available, we relied on information from the local technical staff of the Bahia State Agriculture Defense Agency (ADAB) in order to locate the sub-regions where orange groves were established in each municipality. Transects were planned for each sub-region and the groves were systematically sampled every $5 \mathrm{~km}$. In municipalities where groves were not concentrated in one sub-region the distance between sampled groves was occasionally higher than $5 \mathrm{~km}$ (Figure 1).

In each farm, the groves were randomly selected based on property size and they were georeferenced as a four-sided polygon. Each polygon was evaluated by walking through in a $\mathrm{W}$-shaped path and inspecting individual trees for typical CVC symptoms in the leaves and/or fruits. In order to avoid misclassifications, evaluators were previously trained by an experienced CVC researcher. At least $1 \%$ of the plants of each area were evaluated (Nascimento et al., 2006) and the following variables were recorded: 04 UTM pairs of geographic coordinates; municipality; municipality subregion; grove age; orange variety; rootstock variety; existence of irrigation system; measures adopted for CVC control and proportion of CVC affected trees. Based on the proportion of affected plants, the following variables were estimated for each survey: prevalence (percentage of affected groves in each municipality); mean incidence in affected groves of each municipality (MIAG) and mean municipality incidence (MMI).

The first survey was done in the 2003 dry season, between January and May in both regions (LN and RB). The second survey was done just after the rainy season of 2003 (August to October) in the same groves as the first survey and in seventeen more areas and another three municipalities (Entre Rios, Olindina and Sátiro Dias) in the $\mathrm{LN}$ region. The third survey was done just before the 
TABLE 1 - Sweet orange area (ha) and number of evaluated groves in 19 municipalities of Recôncavo Baiano region, Bahia, Brazil. 2003-2005

\begin{tabular}{|c|c|c|c|c|}
\hline \multirow{3}{*}{ Municipality } & \multicolumn{4}{|c|}{ Surveys } \\
\hline & \multicolumn{2}{|c|}{2003} & \multicolumn{2}{|l|}{$2004 / 2005$} \\
\hline & Sweet orange area (ha) & Number of groves & Sweet orange area (ha) & Number of groves \\
\hline Cabaceiras do Paraguaçu & 510 & 03 & 551 & 06 \\
\hline Cachoeira & 170 & 01 & 175 & 01 \\
\hline Castro Alves & 418 & 05 & 418 & 08 \\
\hline Conceição da Feira & 108 & 01 & 100 & 01 \\
\hline Conceição do Almeida & 771 & 09 & 771 & 24 \\
\hline Cruz das Almas & 1959 & 08 & 1959 & 29 \\
\hline Dom Macedo Costa & 50 & 02 & 50 & 02 \\
\hline Governador Mangabeira & 970 & 07 & 1150 & 28 \\
\hline Jaguaripe & 150 & 01 & 150 & 01 \\
\hline Laje & 43 & 01 & 45 & 01 \\
\hline Maragogipe & 250 & 02 & 270 & 07 \\
\hline Muniz Ferreira & 30 & 01 & 30 & 01 \\
\hline Muritiba & 1130 & 08 & 1160 & 18 \\
\hline Santo Amaro & 80 & 01 & 80 & 01 \\
\hline Santo Antonio de Jesus & 800 & 03 & 800 & 02 \\
\hline São Felipe & 418 & 07 & 418 & 14 \\
\hline São Félix & 130 & 02 & 124 & 05 \\
\hline São Miguel das Matas & 250 & 01 & 250 & 02 \\
\hline Sapeaçu & 1638 & 18 & 1638 & 42 \\
\hline Total & 9875 & 81 & 10139 & 193 \\
\hline
\end{tabular}

TABLE 2 - Prevalence and incidence of citrus variegated chlorosis (CVC) in 12 municipalities of Litoral Norte, Bahia, Brazil. 2003 and 2004

\begin{tabular}{|c|c|c|c|c|c|c|c|c|c|}
\hline \multirow[t]{3}{*}{ Municipality } & \multirow{3}{*}{$\begin{array}{c}\text { Sweet orange area } \\
\text { ha }\end{array}$} & \multirow{2}{*}{\multicolumn{2}{|c|}{ Number of evaluated groves ${ }^{x}$}} & \multirow{2}{*}{\multicolumn{2}{|c|}{$\frac{\text { Prevalence }^{\mathrm{y}}}{\%}$}} & \multirow{2}{*}{\multicolumn{2}{|c|}{$\frac{\text { MIAG }^{\mathrm{w}}}{\%}$}} & \multirow{2}{*}{\multicolumn{2}{|c|}{$\frac{\mathrm{MMI}^{\mathrm{z}}}{\mathrm{o}}$}} \\
\hline & & & & & & & & & \\
\hline & & 2003 & 2004 & 2003 & 2004 & 2003 & 2004 & 2003 & 2004 \\
\hline Acajutiba & 180 & 03 & 03 & 0.0 & 0.0 & 0.0 & 0.0 & 0.0 & 0.0 \\
\hline Alagoinhas & 1150 & 08 & 32 & 0.0 & 3.12 & 0.0 & 10.0 & 0.0 & 0.31 \\
\hline Aporá & 75 & 01 & 03 & 0.0 & 33.3 & 0.0 & 60.0 & 0.0 & 20.0 \\
\hline Catu & 34 & - & 01 & - & 0.0 & - & 0.0 & - & 0.0 \\
\hline Entre Rios & 650 & - & 15 & - & 6.67 & - & 10.0 & - & 0.67 \\
\hline Esplanada & 450 & 01 & 04 & 0.0 & 0.0 & 0.0 & 0.0 & 0.0 & 0.0 \\
\hline Inhambupe & 5350 & 06 & 40 & 0.0 & 12.5 & 0.0 & 13.0 & 0.0 & 1.62 \\
\hline Itapicuru & 6400 & 21 & 55 & 47.6 & 90.9 & 27.6 & 36.2 & 13.1 & 32.9 \\
\hline Jandaíra & 800 & 08 & 07 & 12.5 & 100.0 & 2.2 & 18.6 & 0.62 & 18.6 \\
\hline Olindina & 320 & - & 02 & - & 100.0 & - & 12.5 & - & 12.5 \\
\hline Rio Real & 21000 & 45 & 87 & 31.1 & 77.0 & 11.5 & 29.4 & 3.56 & 22.6 \\
\hline Sátiro Dias & 100 & - & 04 & - & 75.0 & - & 11.7 & - & 8.75 \\
\hline Total & 36509 & 93 & 253 & 26.9 & 54.2 & 4.73 & 30.1 & 4.53 & 19.6 \\
\hline
\end{tabular}

2004 rainy season (March-April) and, for the RB region, a fourth survey was done in the 2005 dry season. The results of the first survey were also considered a primary data set to estimate adequate sample size; two methods were used for this: graphical stabilization of variance and mean (Kranz,
1988) and sample size estimation via t-test (Cochran, 1977). For this second method, an error of $5 \%$ of the mean, i.e. the proportion of affected plants in each sampled grove, was accepted $(\mathrm{P}<0.05)$. This method was also used to estimate the error of the mean $(\mathrm{P}<0.05)$ for each survey. 
TABLE 3 - Percentage of groves and mean CVC incidence per age class in two regions of Bahia, Brazil. 2004

\begin{tabular}{lcccc}
\hline \hline & \multicolumn{2}{c}{ Recôncavo Baiano } & \multicolumn{2}{c}{ Litoral Norte } \\
\hline $\begin{array}{l}\text { Age Class } \\
\text { years }\end{array}$ & $\begin{array}{c}\text { Percentage } \\
\text { of Groves }\end{array}$ & $\begin{array}{c}\text { Mean } \\
\text { CVC incidence } \\
\text { \% }\end{array}$ & $\begin{array}{c}\text { Percentage } \\
\text { of Groves }\end{array}$ & $\begin{array}{c}\text { Mean } \\
\text { CVC incidence } \\
\text { \% }\end{array}$ \\
\hline $0-2$ & 0.0 & 0.0 & 2.4 & 5.0 \\
$3-5$ & 5.0 & 0.0 & 3.3 & 8.0 \\
$6-10$ & 29.7 & 0.0 & 36.5 & 21.0 \\
$>10$ & 65.3 & 0.0 & 57.8 & 20.0 \\
\hline
\end{tabular}

In order to perform an analysis of the CVC regional spatial distribution, a geographic database was created using the Spring 4.2 GIS software (Câmara et al., 1996; INPE, 2006) and the 2001 Brazilian digital official municipality net as background (IBGE, 2006). Each sampling unit was identified by a code at the moment of field data collection, and their latitude and longitude coordinates were associated with the code. Coordinates and codes were downloaded to the geographic database, allowing a correct geographic positioning of different sampling units and also the insertion of other data into an attribute table.

Spatialization of CVC prevalence in LN was done using the digital municipality net, where the MMI values were inserted as a municipality attribute. Prevalence map of CVC incidence in LN for 2003 and 2004 was done by ordinary kriging analysis. Prior to kriging, the spatial covariance structure was modeled and used as a weight of the different sampling units' values in the interpolation procedure (Camargo et al., 2004). Surface analysis, necessary to verify the CVC spatial continuity, showed an anisotropic spatial pattern, with an angle of $14.1^{\circ}$ in 2003 and $17.95^{\circ}$ in 2004. The spherical model was fitted to the experimental semivariogram and its suitability was determined by analysing the residuals and plotting the observed versus estimated values. Interpolation was done using a minimum of four and a maximum of 16 sampling units, considering a range of $5859 \mathrm{~m}$ in 2003 and $10200 \mathrm{~m}$ in 2004. All spatial analyses were performed using the geostatistic module of Spring 4.2 (Câmara et al., 1996; INPE, 2006).

\section{RESULTS}

Surveys. In the four surveys not a single plant with CVC symptoms was found in the RB region. In the first LN survey, CVC was observed in three out of eight assessed municipalities (Table 2), in which the MMI varied from 0.62 to $13.1 \%$ with a decreasing gradient in northwest-southeast direction (Table 2, Figure 2). Similar gradients were also observed for the MIAG and the prevalence (Table 2). Based on data from the first LN survey, the optimum number of samples for a CVC survey should be 49 . In the second LN survey, results were not significantly different from those of the first one (data not shown). Symptomatic plants could not be found in sampled groves of the three municipalities (Entre Rios, Olindina, Sátiro Dias) additionally included in this second survey.

In the third and last $\mathrm{LN}$ region surveys, CVC affected plants were observed in nine out of twelve assessed municipalities (Table 2). In three of them - Itapicuru, Jandaíra and Rio Real - CVC had already been detected in 2003; in the other six - Alagoinhas, Aporá, Entre Rios, Inhambupe, Olindina and Sátiro Dias - the disease had not been previously reported. Of the three municipalities where CVC was not found, only Catu was included in this last survey; Acajutiba and Esplanada had no symptomatic trees in all three surveys.

The gradients observed in the first surveys were also observed in 2004 with the exception of the prevalence gradient (Table 2, Figure 3). In this case, CVC was observed in $100 \%$ of the evaluated groves in Jandaíra, a higher value than in Itapicuru. On the other hand, if one considers the estimated MMI in this last survey, it was possible to observe not only the Itapicuru - Rio Real - Jandaíra gradient but also a northeast-southwest gradient from Itapicuru to Sátiro Dias and a north-south gradient from Itapicuru to Catu (Figure 3).

All variables increased in those three municipalities where CVC was found in the first survey (Tables 2 and 3). Prevalence increased more in Jandaíra than in Itapicuru or Rio Real, while mean incidence of affected groves increased more strongly in Rio Real and Jandaíra than in Itapicuru. Nevertheless, the rise in MMI was similar for all three municipalities.

When $\mathrm{LN}$ was considered as a whole, it was estimated that more than half of its groves had at least one CVC symptomatic plant. Thirty percent was the mean incidence in the groves where $\mathrm{CVC}$ was found, while it was estimated that around $20 \%$ of the orange plants were symptomatic (Table 2). Compared to the 2003 results, a significant increase in all variables - prevalence, MIAG and MMI - was observed.

Horticultural features. In all regions, $100 \%$ of the growers used Pêra sweet orange as canopy variety. In RB, Rangpur lime was the rootstock of $100 \%$ of the groves; in 

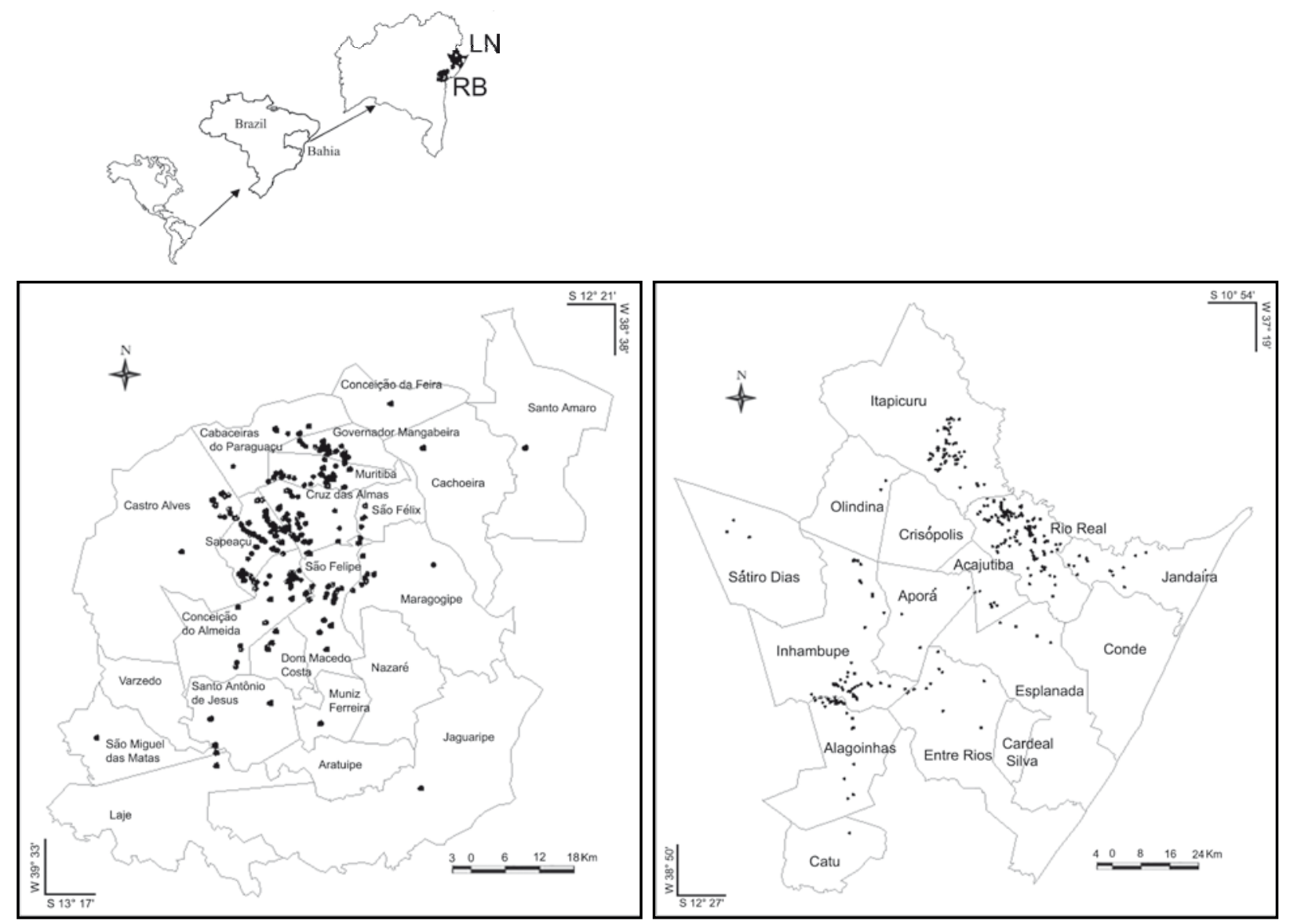

FIG. 1 - Geographic identification of the two surveyed regions (2004), and location and distribution of sampling units (dots) in Recôncavo Baiano A. and Litoral Norte B. regions of Bahia, Brazil.

LN it dropped to $98 \%$, the other $2 \%$ were identified as groves established on Rough (C. jambhiri Lush.) or Volkamer ( $C$. volkameriana Pasq.) lemons.

Irrigation systems (microsprinklers) were used in only three sampled groves in LN. In one of them the percentage of affected plants was $20 \%$ while in the other two no symptomatic plants were found. In only one farm - at Rio Real - control measures against CVC had been adopted by pruning symptomatic plants according to recommendations developed for the State of São Paulo. Since no systematic surveys were carried out, as advised in São Paulo, effective CVC control was done only where citrus integrated production procedures were performed. With respect to the origin of plantlets to establish the groves, both in $\mathrm{RB}$ or $\mathrm{LN}$, $100 \%$ of the growers used either those produced in their own farms or bought from nurserymen of their regions.

Due to the great homogeneity of the cultural practices, varieties and absence of control measures, no comparative analyses of these factors could be done. On the other hand, sampled groves of RB could be sorted into almost all age classes, with the exception of the $0-2$ years group (Table 3 ), and most groves were over ten years old. At LN, the age profile was wider, and around $2.4 \%$ of the groves were aged between 0 and two years (Table 3 ). However, as at RB, most of them were over ten years old. CVC was observed in all tree age classes in LN, although it was more frequent in plants over six years old.

\section{DISCUSSION}

The first survey generated a primary data set used to find an optimum number of samples. The actual used number of samples turned out to be double the required number to obtain a mean of proportion of symptomatic plants with an error of $5 \%$. Nonetheless, based on the spatial aggregation of CVC on a regional level, concentrated in three municipalities, it was decided to enlarge the number of samples in subsequent surveys, hence increasing the odds of detecting symptomatic plants in municipalities with expected low incidence.

Occurrence of CVC in Bahia has been reported in Itapicuru municipality since the last decade of the 20th 

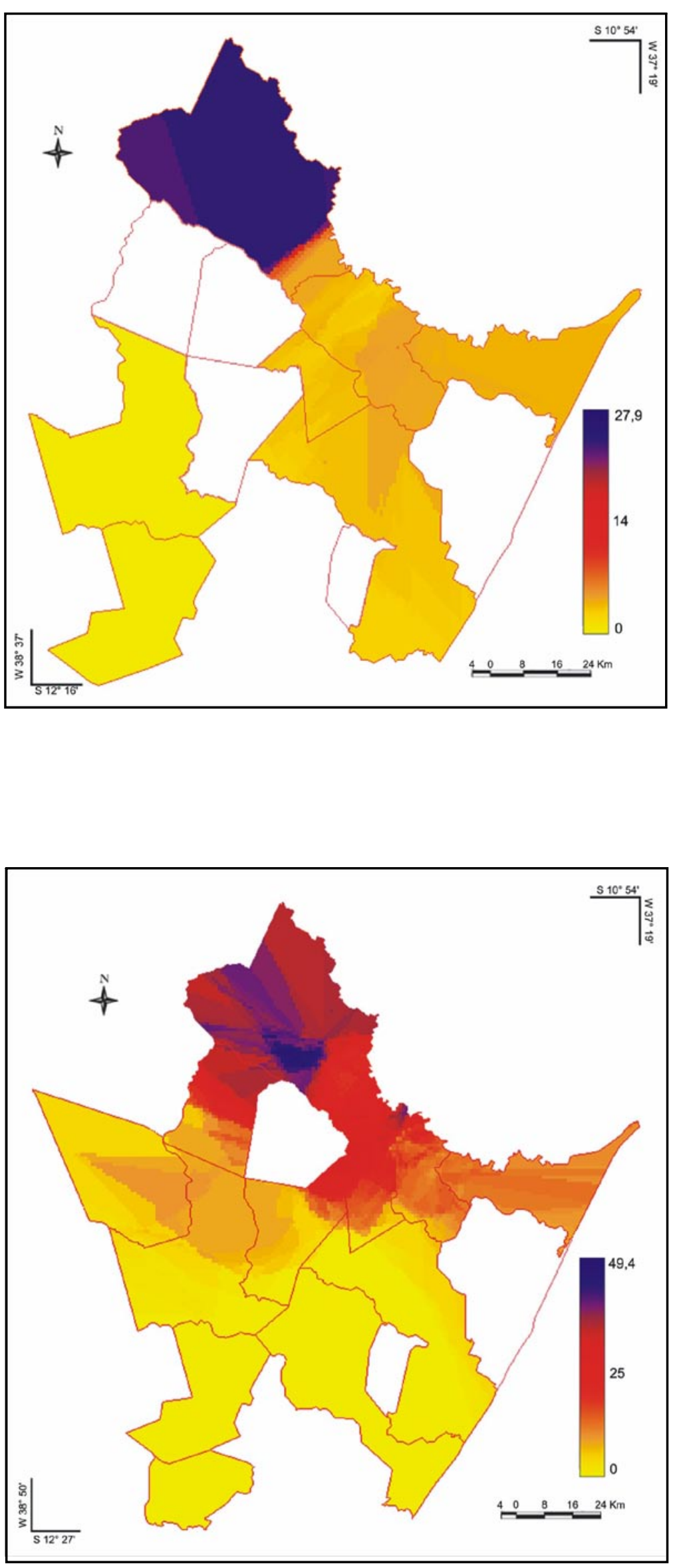

FIG. 2 - Kriging estimated citrus variegated cholorosis (CVC) incidence (\%) map for the 2003 survey in Litoral Norte of Bahia, Brazil. Municipalities in white were not surveyed.
FIG. 3 - Kriging estimated citrus variegated cholorosis (CVC) incidence (\%) map for the 2004 survey in Litoral Norte of Bahia, Brazil. Municipalities in white were not surveyed. 
century (Santos Filho et al., 1997). Therefore, detection of this disease in the $\mathrm{LN}$ region was expected, as well as its higher incidence in Itapicuru and Rio Real municipalities. Moreover, this finding supports our hypothesis that CVC incidence in Bahia is associated with high orange grove density. In Itapicuru, 54\% of all the agricultural area is planted with orange groves, while in Rio Real the proportion reaches $81 \%$. For most LN municipalities the proportion is below 10\% (IBGE, 2004).

Our hypothesis was that CVC would not only be found in $\mathrm{LN}$, but there would be a dispersion gradient. In São Paulo, nine years after the first CVC report, the disease had already been detected in all regions of its citrus belt, and a conspicuous gradient was formed between NorthNorthwest and South regions (Fundecitrus, 2006). In the North-Northwest region where the first affected plants were found, the highest water deficits occur (Laranjeira et al., 2005a). The results of the LN surveys point to a very similar situation: gradients between North LN (Itapicuru) and South LN (Alagoinhas-Catu; Jandaíra), but also having Itapicuru - the municipality where the initial foci of CVC were found in Bahia - as the highest disease incidence sub-region.

We could not analyze a possible influence of germplasm on CVC incidence due to the high homogeneity of varieties used by growers. Even though experimental evidence showed no influence of rootstocks on CVC incidence or severity (Laranjeira et al., 2001), the behavior is different with respect to the varieties used as scion. In fact, all sweet oranges tested so far are susceptible to CVC (Laranjeira et al., 1998; Laranjeira et al., 2005a) whereas some varieties, such as Westin and Lue Gim Gong, are rated as moderately susceptible (Laranjeira \& Pompeu Júnior, 2002). On the other hand, Pêra sweet orange, the most popular variety in Bahia, is considered as highly susceptible (Laranjeira \& Pompeu Júnior, 2002) and thus, the spatial continuity of susceptible genetic material is assured in the entire state citrus belt. A spatial discontinuity of susceptible varieties resulting in a lower CVC spread could be achieved by the use of highly CVC resistant species, such as lemons, acid limes, mandarins and their hybrids (Laranjeira et al., 1998). However, acid lime groves in Bahia do not reach $6 \%$ of the total citrus acreage and mandarin groves barely reach $1.5 \%$ (IBGE, 2004).

Plant age is another factor considered crucial for CVC infection in other citrus producing belts of Brazil. According to Garcia Júnior et al. (1995), plants up to seven years old are more Xylella infection-prone, because they tend to have more vegetative shoots than older trees and hence attract more vectors. Although it is true that CVC vectors prefer young shoots (Leite \& Nakano, 2000; Parra et al., 2005) and younger plants have more vegetative flushes than older ones (Spiegel-Roy \& Goldschmidt, 1996), it does not mean younger plants are more susceptible to CVC infection. The LN data show that age classes with higher proportions of symptomatic plants are those over six years old. However, it is possible that those plants were infected when younger.
As a matter of fact, the frequency of CVC affected plants in each age class at $\mathrm{LN}$ is very similar to the present frequencies in the State of São Paulo (Fundecitrus, 2006). Nevertheless, when surveys were started, the proportion of symptomatic plants was higher among young trees up to five years old (Fundecitrus, 2006). In São Paulo, the change in the proportion of symptomatic plants according to age classes is attributed to the efficiency of CVC control in nurseries and very young groves in most recent years (Fundecitrus, 2006). In Bahia that would not be a satisfactory explanation, since only a negligible number of growers try to control the disease. The higher proportion of affected adult plants at LN may be seen as an indication that younger plants are not subjected to high infection rates. However, if the establishment rate of new groves starts to increase, this situation may change very fast, because old symptomatic groves are important inoculum sources (Laranjeira et al., 2005a).

The mean proportion of symptomatic plants found in LN in the last survey (19.6\%) - seven years after the first CVC report in Bahia - is close and comparable to what was found in 1996 in the State of São Paulo (22.1\% - Fundecitrus, 2006), nine years after the first report of CVC. This similarity is an indication that CVC progress in LN does not differ significantly from what is observed in other environments. Those proportions are also equivalent because they reflect past situations in São Paulo and present ones in Bahia - when CVC progressed in the absence of control measures.

Although the detection and dispersion of CVC in $\mathrm{LN}$ was expected, the absence of the disease in $\mathrm{RB}$ was somehow surprising. If cultural practices are considered, these two regions are different, but they are not separated by any natural barrier. Moreover, there was no restriction on the movement of citrus material - fruits, plantlets or budwood - between them. Considering that no attempt to control $\mathrm{CVC}$ is made by citrus growers and also no quarantine or regulatory actions are taken, presence of the disease would be expected in the majority of municipalities where citrus is grown. The non-detection of CVC in RB has three possible explanations. The first one is the spatial discontinuity of orange groves; although both regions $-\mathrm{LN}$ and $\mathrm{RB}-$ are adjacent, there is a gap of about $100 \mathrm{~km}$ between the last grove of one region and the first of the other. In this $100 \mathrm{~km}$ zone, there are no commercial citrus groves, only backyard orange trees. Obviously, this gap represents a barrier to a continuous dissemination towards the South by means of insect vector dispersion. The second possible explanation is the use of healthy propagation material. After CVC was detected in Bahia, research institutions made an effort to produce healthy budwood. In order to certify budwood as disease-free, both mother plants and bud producing trees are kept under screen-protected greenhouses. The budwood production center is the municipality of Cruz das Almas, located in RB, a situation that has a direct influence on citrus nursery production methods in that region. The last factor is the tradition of RB growers to produce their own 
nursery citrus plants. In so doing, they avoid bringing infected but asymptomatic plants to their region. Although local production of nursery plants is as common in $\mathrm{LN}$ as it is in RB, the existence of local inoculum sources in LN turns the situation into a negative factor considering CVC dissemination. It happens because nurseries in Bahia - not screen-protected and located near old and possibly infected groves - do not follow the rules and recommendations to avoid disease infections (Carvalho, 2003; Passos \& Rezende, 2003).

Even though CVC has been reported in Bahia since 1997, up to now no specific surveys have been done in this citrus belt. Our results show that CVC, although disseminated in the main citrus region in Bahia, is still not found in RB and this absence may be related to control measures such as the use of disease-free propagation material. Based on these results, the Bahia State Agriculture DefenseAgency (ADAB), decided to ban the transit of citrus propagation material between CVC affected municipalities and other regions (Decree $\mathrm{n}^{\circ} 119$, March 28, 2005). Of course, considering the importance of citriculture in Bahia, especially for small growers in RB, it would be highly advisable to promote more frequent surveys in order to launch eradication measures as soon as required.

Exclusion measures or even eradication would no longer be effective in LN. In São Paulo the efficiency of roguing out symptomatic plants younger than two years is well known, or even those up to four years old bearing symptomatic fruits, to decrease CVC progress. For plants over four years old, pruning of symptomatic branches is now a common practice (Garcia Júnior et al., 1995; Fundecitrus, 2004; Laranjeira et al., 2005b). Also, it is advisable to protect newly established groves by insecticide spraying or application of systemic insecticides on the trunks (Fundecitrus, 2004; Laranjeira et al., 2005b). Nevertheless, the use of healthy propagation material and nursery plants is more important. In São Paulo, after the mandatory use of screen-protected nurseries in 2003 (Carvalho, 2003), there was a substantial decrease in the percentage of symptomatic plants in groves up to five years old (Fundecitrus, 2006). As the use of screen-protected nursery plants continues, a CVC incidence decrease in all age classes is expected. Promoting the establishment of that kind of nursery should be a priority in LN.

Even if considered as a secondary action, it would be very important to promote higher cultivar diversity in citrus groves of Bahia. The massive use of the highly susceptible Pêra cultivar makes Bahian citriculture even more vulnerable. It would be especially useful to promote spatial discontinuity by planting groves of acid limes, mandarins, tangelos and tangors, species and hybrids known to be CVC resistant (Laranjeira et al., 1998). Exclusion or eradication measures, even those that cannot be regionally considered in LN, can still be advised for application at farm or sub-region level. Those practices include the use of healthy nursery plants, but also the removal of symptomatic plants or branches.
In general, throughout these surveys a lack of awareness concerning CVC control was noted. Apparently, growers simply do not know what can be done and sometimes are not able to recognize the disease itself, even after noticing the effects on their groves. However, the detection of critical factors for CVC control in Bahia, presented here, may represent an opportunity to improve the knowledge of Bahia citrus industry decision makers.

\section{ACKNOWLEDGEMENTS}

The authors wish to thank the European Commission (ICA4-CT-2001-10005) for financing this research, Conselho Nacional de Desenvolvimento Científico e Tecnológico $\mathrm{CNPq}$ for a research grant for the first author and Mr. Décio de Oliveira Almeida (FAPESB grant BOL 0053/2005) for technical support.

\section{REFERENCES}

Aguilar E, Villalobos W, Moreira L, Rodríguez CM, Kitajima EW, Rivera C (2005) First Report of Xylella fastidiosa Infecting Citrus in Costa Rica. Plant Disease 89:687.

Ayres AJ, Gimenes-Fernandes N, Barbosa JC (2001) Intensidade da clorose variegada dos citros no Estado de São Paulo e Sul do Triângulo Mineiro. Summa Phytopathologica 27:189-197.

Câmara G, Souza RCM, Freitas UM, Garrido J, Mitsuo F (1996) SPRING: Integrating remote sensing and GIS by object-oriented data modelling. Journal of Computational \& Graphical Statistics 20:395-403.

Camargo ECG, Fucks SD, Câmara G (2004) Análise Espacial de Superfícies in: Druck S, Carvalho MS, Câmara G, Monteiro AVM (Eds.) Análise Espacial de Dados Geográficos. EMBRAPA, Brasília DF.

Carvalho SA (2003) Regulamentação atual da Agência de Defesa Agropecuária para produção, estocagem, comércio, transporte e plantio de mudas cítricas no Estado de São Paulo. Laranja 24:199239.

Cochran WG (1977) Sampling Techniques. New York NY. John Wiley \& Sons.

Fundecitrus (2004) Manual de CVC. Fundecitrus, Araraquara SP.

Fundecitrus (2006) CVC Statistics. www.fundecitrus.com.br/ english/est_cvc_us.html.

Garcia Júnior A, Maggione CS, Teófilo Sobrinho J, Pompeu Júnior J, Denegri JD, Quaggio JA, Beretta MJ, Gravena S, Rodas VZ (1995) Como conviver com a CVC em São Paulo. Laranja 16:145154.

IBGE (2004) Banco de Dados Agregados. Sistema IBGE de Recuperação Automática - SIDRA. [http://www.sidra.ibge.gov. $\mathrm{br} / \mathrm{bda}]$.

IBGE. (2006) Download Geociências: Mapas: Malhas_digitais: Municipio_2001: BA: 29mu2500g.shp. [http://www.ibge.gov.br/ servidor_arquivos_geo/]. 
INPE (2006) Spring: Sistema de Processamento de Informações Georeferenciadas. [www.dpi.inpe.br/spring].

Kranz J (1998) Measuring plant disease. In: Kranz J, Rotem J (Eds.) Experimental Techniques in Plant Disease Epidemiology. Heidelberg. Springer Verlag. pp. 35-50.

Laranjeira FF, Pompeu Júnior J (2002) Comportamento de Quinze Cultivares de Laranja-Doce Afetadas pela Clorose Variegada dos Citros. Laranja 23:401-411.

Laranjeira FF, Bergamin Filho A, Amorim L, Aguilar-Vildoso CI, Coletta Filho H (2005a) Fungos, procariotos e doenças abióticas. In: Mattos Júnior D, DeNegri JD, Pio RM, Pompeu Júnior J (Eds.), Citros. Instituto Agronômico and Fundag, Campinas SP. pp. 509566.

Laranjeira FF, Feichtenberger E, Bassanezi RB, Spósito MB (2005b) Manejo integrado de doenças de citros. In: Mattos Júnior D, DeNegri JD, Pio RM, Pompeu Júnior J (Eds.), Citros. Campinas SP. Instituto Agronômico and Fundag. pp. 629-654.

Laranjeira FF, Müller GW, Vaz Filho D \& Pompeu Junior J (2001) Porta-enxertos não influenciam na expressão da clorose variegada dos citros (CVC) em laranjas-doces. Revista Brasileira de Fruticultura 23:212-214.

Laranjeira FF, Palazzo D (1999) Danos qualitativos à produção de laranja 'Natal' causados pela clorose variegada dos citros. Laranja 20:77-91.

Laranjeira FF, Pompeu Júnior J, Harakava R, Figueiredo JO, Carvalho SA, Coletta Filho HD (1998) Cultivares e espécies cítricas hospedeiras de Xylella fastidiosa em condição de campo. Fitopatologia Brasileira 23:147-154.

Leite CA, Nakano O (2000) Distribuição vertical e horizontal de três espécies de cicadelídeos em plantas de citros. Laranja 21:271288.

Nascimento AS, Santos Filho HP, Sanches NF, Silva LG, Magalhães KCL, Melo RL (2006) Monitoramento de pragas na cultura dos citros: pragas regulamentadas e inimigos naturais. Embrapa Mandioca e Fruticultura Tropical, Cruz das Almas BA.

Palazzo DA (1993) Estimativas de perdas de laranja Natal por clorose variegada dos citros. Laranja 14:211-226.

Parra JRP, Lopes JRS, Zucchi RA, Guedes JVC (2005) Biologia de insetos-praga e vetores. In: Mattos Júnior D, DeNegri JD, Pio RM, Pompeu Júnior J (Eds.), Citros. Instituto Agronômico and Fundag, Campinas SP. pp. 655-687.

Passos OS, Rezende LAN (2003) Citricultura no Estado da Bahia - diagnóstico sobre a produção de mudas. Embrapa Mandioca e Fruticultura, Cruz das Almas BA. (Circular Técnica 55).

Santos-Filho HP, Barbosa CJ, Meissner-Filho PE, Ribeiro JS, Santos JL, Matrangolo WJR, Miranda MP, Sodré GS (1997) Ocorrência da clorose variegada dos citros em pomares do Estado da Bahia. Fitopatologia Brasileira 22:234-235.

Schaad NW, Postnikova E, Lacy G, Fatmi, Chang CJ (2004) Xylella fastidiosa subspecies $X$. fastidiosa subsp. piercei, subsp. nov., $X$. fastidiosa subsp. multiplex subsp. nov., and $X$. fastidiosa subsp. pauca subsp. nov. Systematic and Applied Microbiology 27:290-300.

Spiegel-Roy P, Goldschmidt EE (1996) Biology of Citrus. Cambridge. Cambridge University Press.

Tersi FEA, Rigolin AT (2000) Impacto da clorose variegada dos citros no custo de produção de cinco propriedades do Centro e do Norte paulistas. Laranja 21:29-38.

Received 26 November 2007 - Accepted 15 September 2008 - TPP 7135 Associate Editor: Lilian Amorim 